\title{
CARE AND ACADEMIC MOTHERHOOD: CHALLENGES FOR RESEARCH AND TENURE IN THE CANADIAN UNIVERSITY
}

\author{
YVONNE JAMES \\ UNIVERSITY OF OTTAWA \\ STEPHANIE GAUDET \\ UNIVERSITY OF OTTAWA \\ IVY BOURGEAULT \\ UNIVERSITY OF OTTAWA \\ MERRIDEE BUJKAI \\ CARELTON UNIVERSITY
}

\begin{abstract}
In Canada, women are earning an increasing number of doctoral degrees; yet, they are less likely to secure a tenure-track position. A feminist thematic analysis of semi-structured interviews with 20 academic mothers from two Canadian universities reveals the range of challenges that mothers encounter in relation to care on the tenure-track. First, the theme of "fear of post-partum academic erasure" captured faculty mothers' experiences of feeling compelled to assert their physical and intellectual presence in post-partum during peak periods of infant care. The second theme, "the mommy tenure track and care choices," encapsulated academic mothers' experiences of feeling unsupported by the university in their pursuit of promotion and tenure given care responsibilities associated with motherhood. The final theme, "research while caring," captured the tensions academic mothers experience between the research process and caring. The findings of this research are particularly relevant in a pandemic and post-pandemic environment, where academic mothers have seen their care work swell to unprecedented proportions.
\end{abstract}

Keywords: academic motherhood, care work, tenure track, discrimination, family care

\section{Résumé}

Au Canada, les femmes sont de plus en plus nombreuses à obtenir un doctorat, mais elles ont moins de chances que les hommes de décrocher un poste menant à la permanence. Une analyse thématique féministe d'entrevues semi-structurées effectuées auprès de 20 mères menant une carrière universitaire dans deux universités canadiennes révèle l'éventail des défis qu'elles rencontrent en matière de soins sur le chemin qui les mène vers l'obtention de leur poste permanent. Le premier, la " peur de l'effacement post-partum ", décrit l'expérience des mères qui se sentent obligées d'affirmer leur présence physique et intellectuelle pendant les périodes de pointe des soins aux nourrissons. Le deuxième, "la voie vers la titularisation et les choix en matière de soins ", résume les expériences des mères qui ne se sentent pas soutenues par l'université dans leur quête de promotion et de titularisation compte tenu des responsabilités associées à la maternité. Le dernier, " la recherche tout en s'occupant des enfants ", illustre les tensions que vivent les mères entre les exigences de la recherche et celles des soins. Les résultats de cette recherche sont particulièrement pertinents dans un environnement pandémique et post-pandémique, où les mères ont vu leur travail de soins prendre des proportions sans précédent.

Mots-clés : maternité, permanence universitaire, travail de soins, discrimination, soins familiaux

\section{Introduction}

The retention and promotion of women faculty in academia has become an area of increasing interest nationally as well as internationally. In Canada, women are earning a growing share of doctoral degrees, yet they are less likely 
than men to secure tenure-track positions (Drakich et al., 2007; Statistics Canada, 2020; University Affairs, 2017). Further, although women made up $40 \%$ of full-time faculty members, according to the 2017 University and College Academic Staff System (UCASS) Statistics Canada survey, ${ }^{1}$ men overwhelmingly dominated the ranks of full and associate professors (University Affairs, 2017). The concentration of men in full and associate positions has meant that they remain the top earners and in top leadership positions, while the gap for women in these positions is the largest (Momani et al., 2019). Women's experiences on and toward the tenure track are further challenged by gendered expectations of care-both at home and at work. Although there is ample research on the tensions between academic motherhood and attaining a tenure track position (Acker \& Armenti, 2004; Armenti, 2004; Hirakata \& Daniluk, 2009; Thanacoody et al., 2006; Valian, 2005; van Anders, 2004; Wolf-Wendel \& Ward, 2006), there is less known about the care experiences of academic mothers on the tenure track.

Family formation, motherhood, and child rearing pose significant challenges to academic women. Academic women in general, but mothers in particular, face significant challenges on the tenure track, and even after tenure and promotion to associate, they are less likely to be promoted to full professor (Mason et al., 2013). Wolfinger and associates (2008), for example, noted that the first major career transition typically encountered by new PhDs, the procurement of a tenure-track professorship, is affected by family formation. Women who have at least one child within five years post-doctorate are significantly less likely to achieve tenure than men who have children early in their careers (Mason et al., 2013). Consistent with this, an earlier study of female assistant professors found over $40 \%$ reported factors such as the time they spent on children to be serious impediments to achieving tenure (Kolker et al., 1996). Among academic parents, it is academic mothers, rather than fathers, who experience higher levels of work-life conflict and stress (Hill et al., 2011; Wilton \& Ross, 2017).

An oft used metaphor to help explain women's under-representation in tenure track positions and at the highest levels of academic leadership is the leaky pipeline (e.g., Gasser \& Shaffer, 2014). According to this metaphor, academic women fall out of the academic progress pipeline at key junctures related to significant life events such as marriage/partnership, pregnancy, birth, and family formation. This conceptualization is problem- atic, however, because it conceives the leaking process as passive, like the gravity that pulls water from a pipe. A more complex conceptualization is necessary to more fully understand the dynamics at play. In this article, we explore academic mothers' experiences of care both toward and on the tenure track in the university, in their own words, through the conceptual lens of care work. The key questions that guided this study included the following: How do academic mothers describe and experience care in academia? How do academic mothers experience care on and toward the tenure track? How do academic mothers describe and experience care in relation to their research? Our focus on care in academia enables us to advance a more thoughtful dialogue of how the care undertaken by academic mothers pulls women away from the academic progress pipeline in a way that may be invisible to academia more broadly.

\section{Care Work as a Theoretical Frame}

Care work as a theoretical frame helps us to understand academic mothers' tenure track experiences from the perspective of gendered care. More specifically, care work as a theoretical frame highlights the ways in which gendered care work functions in the university, which is organizationally and professionally gendered masculine. It is helpful to begin by identifying the features of care work that are important to a discussion of academic mothers' experiences of care work on the tenure track. Most of the activities that are categorized as care work are typically performed by women and are tied to the social reproduction of human beings (Benoit \& Hallgrimsdóttir, 2011; England, 2005). This kind of social reproduction work refers both to women's biological (e.g., literally birthing human beings) and social roles (e.g., feeding, clothing, caring, cleaning, etc.) in reproducing labour power "on a daily and generational basis" (Armstrong \& Armstrong, 2002, p. 45).

The role of gender in ascribing social reproductive tasks to women and its location in the domestic sphere makes this work largely invisible to the formal world of work and workplace policy, though this is changing based on work-from-home policies implemented during COVID-19. It is often conceptualized as the work that women just do, and as such is largely unpaid, or if purchased, underpaid (Allen et al., 2008). The gendering of care work produces a logic of care that appears to 
function in opposition to the market and exchange value. In the absence of a tangible product, the relatively invisible and immeasurable care work is devalued both at home and in the market (Allen et al., 2008). England et al. (2002) also suggests that the devaluation of care work may stem from the cultural construction of motherhood, which is based on an ideology of domesticity "underpinned by a set of gendered moral obligations" (p. 457). Gottried (2013) asserted that common sense understandings expect care to be given freely and rewarded in terms of its intrinsic use-value, rather than compensated monetarily. Reverby (1994) described this as a caring dilemma, whereby women are socialized into care work responsibilities in a societal context where this work is devalued. The invisibility and devaluing of family care work have considerable and synergistic negative implications for women's work more broadly (Daniels, 1987; Star \& Strauss, 1999).

Tronto's (1993) conceptualization of care in Moral Boundaries: A Political Argument for an Ethic of Care advanced this dialogue. Care, Tronto argues, is not a disposition, nor is it a moral obligation, set of rules, or principles. Rather, it is a political idea and set of practices that take as their starting point both the essential interdependency of all human beings-or "the fact that not all humans....in the world are equally able, at all times, to take care of themselves" (p. 162) -and the central role of caring in daily human life. Care practices, Tronto elaborated, include attentiveness, responsibility, competence, and responsiveness, and go beyond care work. For Tronto, care is broadly defined as maintaining human, animal, and vegetal life.

Tronto (1993) rejects terms like "women's work" when theorizing care because these terms refer to an image of women that has historically excluded many women from its purview. Moreover, theoretical arguments that have associated women's morality (e.g., natural disposition towards caring) with care have been unsuccessful in advancing care theory because they are dismissed as irrelevant to given political circumstances. Feminists adopting her point of view underline the fact that care is gendered, yet aim to separate it from unproblematized notions of women's nature (Bourgault \& Perreault, 2013).

\section{Academic Motherhood}

Like mothers outside of the academy, academic mothers are responsible for more care work, including childcare and household responsibilities, than men, and as a result experience more work/family stress (Armenti, 2004; Castaneda \& Isgro, 2013; Denson et al., 2018; Hirakata \& Daniluk, 2009; O'Laughlin \& Bischoff, 2005). In the Faculty and Families Project, Drago and Williams (2010) reported that because women make up the majority of caregivers in our society, regardless of employment status, the ideal worker model (Ward \& Wolf-Wendel, 2016) currently favoured in academic settings is discriminatory against women. Drago and Williams (2010) called on the academy to cease measuring commitment by the ability of an academic to have a spouse ready, willing, and able to shoulder the child-caring during the most time-consuming years of child rearing-when the children are young. More recent studies suggest that the current system is markedly similar to the one critiqued by Drago and Williams nearly 20 years ago (Hill et al., 2011). For example, academic mothers who attempt take advantage of family-friendly policies, such as extension of the tenure clock to care for an infant, often face negative consequences in terms of tenure and promotion, and struggle transitioning back to work following leave (Bonawitz \& Andel, 2009; Hill et al., 2015; Kandiko et al., 2018; Spalter-Roth \& Erskine, 2005; Williams, 2004)

It is well documented that academic mothers who shoulder the bulk of care work consequently face significant challenges securing tenure-track positions and reaching promotion (Acker et al., 2012; Wilton \& Ross, 2017). Drago et al. (2005) found that faculty mothers, when confronted with departmental bias against caregiving (i.e., care work), chose among three strategies: to accept, avoid, or resist. In practice, the avoidance strategy means that some faculty mothers strive to keep their family lives rigidly separate from their university commitments, while others chose to actively resist the separation of family and academy, decorating their offices with pictures of or by their children or occasionally bringing their children to campus. This study contributes care-based insights to the existing body of literature that describes and reports the tensions between academia and motherhood (Bosanquet, 2017; Kandiko et al., 2018; Ward et al., 2019). There is a robust scholarship on the tensions that exist between academia and motherhood, but this literature does not fully address the more nuanced (i.e., visible and invisible) care processes that academic mothers experience on the tenure-track. With this gap in mind, we explore academic mothers' experiences of motherhood and care work on the tenure track 
with the objective of making academia mothers' care experiences visible within the tenure-track trajectory.

\section{Methods}

In-depth semi-structured interviews with 20 women of varying ranks at two Canadian universities (10 at each) provided rich data for a feminist analysis of their experiences. Interviews were facilitated jointly by the four authors across two Canadian university sites in the same city before the onset of the COVID-19 global pandemic. At the time of interviews, the first author was a doctoral student and visibly pregnant. The other three authors, all mothers, held senior academic faculty positions in the areas of management, accounting, and sociology. The protocol was approved by the Research Ethics Boards at both universities where the data were collected.

\section{Participant Selection and Recruitment}

Participants were recruited via an e-mail recruitment letter distributed by the institutional union listservs, as well as through the authors' professional and personal networks. Participants were recruited based on their experiences as women navigating work and health at either of the two universities under examination. Both universities are located in the same mid-sized Canadian city. Participants were not recruited based on their experiences as mothers in academia, though this emerged as a significant area of analysis from the interviews. Twenty-two women participated in interviews and 20 of those interviewed identified themselves as mothers. For the purpose of this study, we did not include interviews with participants who did not identify themselves as mothers, but those interviews were included in analyses outside of this article. Part-time and contract professors were not exempt from participation, though none responded to the recruitment call. Participation was encouraged from across faculties and departments, in particular from those in the Science, Technology, Engineering, and Mathematics (STEM) fields, given they can be under-represented in this type of research. All of the women recruited consented to participation in a life history interview, as well as to complete a pre-interview life course calendar exercise. The life course calendar data was not used explicitly in the development of this analysis as it has been reported elsewhere (Gaudet \& Robert, 2018).

\section{Participants}

The 20 participants, 10 from each university, came from diverse faculties and departments, including but not limited to: human kinetics, public affairs, biology, engineering, occupational therapy, women's studies, business, and psychology. We interviewed participants at the rank of assistant $(n=6)$, associate $(n=10)$, and full ( $n$ $=4$ ) professor. All participants self-identified as cis-gendered women. Participants reported annual household incomes of greater than $\$ 100,000$. All of the participants were in long-term supportive relationships (e.g., married or common law). At the time of data collection, all of the participants were currently in a tenure-track position within their university; the life history interview (noted above) worked to reflect experiences of care work and academic motherhood over the complete life course, from pre- to post-tenure track, rather than at one point in time. Participants were not guaranteed anonymity due to the somewhat insular nature of Canadian academia, but every effort was made throughout the reporting stage of this project to protect the identities of participants.

\section{Data Collection}

Interviews followed feminist principles of qualitative inquiry (Oakley, 1981) and were guided by semi-structured questions on women's experiences of work and care over the life course (Gaudet, 2013). The interview guide included questions and prompts regarding academic women's experiences in four distinct areas: work issues, health issues, leaves of absence, and return to work issues, and impact on career trajectory. Participants were asked questions that directly related to care work in academia, including the following: What impact do you think care work has had on your research productivity and quantity, topic, how you chose to study (e.g., qualitative, quantitative, travel, conference attendance) teaching, supervision, and service work? What impact have your family's care needs had on your ability to travel and collaborate internationally? How would you describe your career progress as compared to peers in your field? The majority of interviews occurred face-to-face and all interviews were individual; that is, only one person was interviewed at a time by one interviewer. Interview time and location were nominated by the participants. Interviews were audio recorded, transcribed verbatim and anonymized before uploading to NVivo (QSR Interna- 
tional, 2012) for thematic analysis. Data saturation was reached after the authors interviewed 10 women from each university.

\section{Data Analysis}

In broad terms, thematic analysis is understood as a method for "analyzing and reporting patterns (themes) within data" (Braun \& Clarke, 2006, p. 79). A theme, Braun and Clarke (2006) argued, captures something important about the data in relation to the research question and "represents some level of patterned response or meaning within the data set" (p. 82). Braun and Clarke (2006) identified six steps in thematic analysis to help researchers locate thematic analysis in relation to other qualitative analytic methods: familiarizing yourself with your data, generating initial codes, searching for themes, reviewing themes, defining and naming themes, and producing the report (see Table 1 ).

Adopting a feminist approach foregrounded themes related to power and dominance in academia. In particular, a feminist iteration of data analysis underpinned engagement with typically marginalized experiences of motherhood in academia. Further, a feminist thematic analysis works toward the feminist objective of recovering and valuing women's experiences-this is particularly important within historically and traditionally masculine professions like academia, where these experiences are at the fringe of inquiry and legitimacy (Rich, 1995).

In this article, quotes are attributed to participants using randomly generated pseudonyms. Where needed for clarity and brevity words have been inserted into

Table 1

Thematic Analysis Process

Braun \& Clark Thematic

Analysis Process

Application in this Project

1. Familiarize yourself with The four authors jointly read a selection of the transcripts to familiarize themselves your data with the data. The authors met on four occasions to report on their initial reading and discuss data saturation in order to determine if data collection should continue. When all authors were satisfied with data saturation (i.e., repeating themes, broad representation across departments and disciplines, and equal representation from both universities), they jointly produced an initial coding scheme.

2. Generate initial codes

An initial coding scheme was created by all four authors after reading the interview transcripts. The draft coding scheme reflected the authors' initial reflections on the interviews they conducted as well as the original objectives of the project (i.e., to explore health issues that affect women on the tenure track).

3. Search for themes

The authors conducted a second reading of the transcripts. During the second reading, the authors generated and searched for new or unanticipated themes. This step highlighted motherhood, care work, and care as core themes across all interviews.

4. Review themes

The authors convened on three occasions to discuss themes and calibrate findings. A final review of the themes confirmed consistent findings across all four authors' review.

5. Define and name themes

Each author defined and named themes that were specific to their manuscript. For this article, the authors defined and named themes around tenure, motherhood, care, and care work.

6. Produce the report The first author led and produced the draft with significant input by the second author. The final manuscript was reviewed by all authors and revised accordingly. 
quotes (denoted by square brackets) or omitted (denoted by an ellipsis). Participants are recognized in this article using rank, but not by department or home university; qualifying participants by department and university would be a threat to their anonymity. Participants were not explicitly asked to define their role as a mother, but rather demographic questions related to caregiving status and the presence of dependents within the home were used to determine if the participant was a mother while on or working toward the tenure track.

\section{Key Findings Related to Academic Motherhood and Care}

Three intertwined themes were identified related to academic motherhood and care. These are listed somewhat chronologically, based upon the order they were typically encountered during the careers of academic mothers. First, the "fear of post-partum academic erasure," emerged early in academic motherhood, capturing faculty mothers' experiences of feeling compelled to assert their physical and intellectual presence in the post-partum period, particularly during a maternity leave during a time of increased care responsibilities. The second theme, "the mommy tenure track," encapsulated faculty mothers' experiences of feeling unsupported by the university in their pursuit of tenure given care responsibilities associated with motherhood. The third theme, "research while caring," captures the tensions academic mothers experience between the research process and care and, subsequently, in response to these tensions, how they may pivot research priorities, programs, and objectives in the post-partum period.

\section{Fear of Post-Partum Academic Erasure during Peak Periods of Care}

In Canada, parental and maternity leave benefits available through both the university as the employer and the government vis-à-vis employment insurance facilitate an initial post-partum period that is typically characterized by an extended maternity and parental leave to account for peak periods of infant care in the post-partum period. Unfortunately, the long hard fight for appropriate maternity and parental leave has engendered new and far less visible barriers for women in the academic workforce. Academic mothers reflected on the cumulative impact of maternity and parental leave during peak periods of infant care on their academic careers in terms of loss: loss of productivity, loss of collaboration, and loss of publications. Erica reflected on how her maternity leave impacted her research program:

It affects quantity, for sure, because it's just...I think it just takes that bit more hours to diversify, to generate more funds, to do all of that. And then the interruptions obviously have been just huge in that you're recruiting during [maternity and parental leave]...I lost continuity. So, the impact is that everything is just that much slower. My program is that much smaller.... That's okay but I can see it, you know.

In addition to concerns about continuity and productivity, for many participants the post-partum period prompted fear of academic erasure, as they feared being made invisible during maternity leave and the added time constraints induced by a peak period of infant care. This was both tangible, in the form of losing research funds, grad students, or their academic position altogether, and intangible, by way of a decreased physical presence on campus or in the lab, which led to a perceived loss of potential collaborators and missed opportunities for grants and publication. For example, during her maternity leave in the late 2000s, Sandra describes trying to combat this potential erasure process in the post-partum period by physically visiting her lab during her maternity leave with her child to establish a continued and ongoing presence:

I was not in my career, in my job for very long, so that was very challenging because I was new...I was worried about my job. So, over the course of my maternity leave, I came into work once a week with my baby. Basically, just to be seen, to make sure I was still contributing to the projects I was leading, and I had grad students as well so I was, sort of needing to keep on top of things.

The perceived need to be physically and visibly present in the office combined with the pressure to produce academic products as a mid-career researcher, similarly prompted Nida to work throughout her maternity leave:

Yeah, so I did stay home. But after about three months, I knew l'd go snaky if I didn't do a little something. So, I actually had babysitters come in from the [early childhood education] program at [local college]. 
And they would come into the house and look after [the baby] for a couple of hours while I just went to my office and did a little bit of work.

After returning to work and beyond the initial peak period of infant care, Nida expressed feelings of guilt when she would leave her office at four o'clock to bring her child to an extracurricular activity. She reflected, almost comically, on the perceived requirement to be constantly visible and ever present, to the point of being inhuman.

Because you're supposed to be there and be visible and be in the office. And I don't know how the senior administration here works because they're robots. Because they go from meeting to meeting to meeting with no food, no breaks. They never have to pee. And I thought am I the only human being here who gets hungry? Come on!

Academic mothers experience fear of academic erasure in the post-partum period when they are on maternity or parental leave to accommodate the intense care needs of an infant. They are worried that the lack of a physical presence in their labs or offices will have major negative implications for their research programs, graduate students, and even their academic positions. In disciplines that do not generally necessitate a wet lab or constantly occupied office space, like social sciences for example, mothers were not as concerned with a lack of physical presence (i.e., due to maternity leave), but rather their ability to be continuously available for contact by colleagues, collaborators, and students, which is hampered by the intense period of care that characterizes the post-partum period with an infant. Participants reflected on how they tried to circumvent academic erasure by teleworking from home through maternity leave or physically visiting their lab with baby in tow. Academic mothers experienced an overall slowing of their productivity in the post-partum period following the initial intensity involved with infant care, which they described as a new and persisting norm throughout their careers. Perhaps in a cruel ironic twist, it is often the maternity leave itself-a major accomplishment in Canadian social policy intended to accommodate and attend to the immediate peak period of infant care-and the resulting physical absence from the workforce that induces perceived academic erasure in the immediate post-partum period. From here, academic mothers watch as their productivity slows as collaborations become complicated, grant opportunities missed, and research programs minimized. Many subtly shifted from the competitive academic tenure-track to the mommy-track.

\section{The Mommy Tenure Track and Care Choices}

The idea of mommy-tracking was popularized in relation to female lawyers in a New York Times article, which said "women who choose to put in fewer hours and spend more time with their families...are considered less serious by their male colleagues" (Williams, 2000, p. 72). By the 1990s, the mommy track had become a common idiom for a career path in which women chose work arrangements that were compatible with bearing the main responsibility for raising children (O'Brien, 2009). While it is certainly true that working people, including academics, who are parents may benefit from certain work arrangements, such as flexible hours, diminished work responsibilities, or the ability to work from home (in the pre-pandemic period), that has almost always come at the cost of fewer opportunities for advancement, less responsibility and authority, and reduced income (Beigi et al., 2018; O'Brien, 2009). In academia, the mommy track runs parallel with the competitive and fast-paced tenure track, placing academic mothers in a disadvantaged position as a result of either their real or perceived care choices. AU.S. study shows that gender neutral parental leaves, wherein men take an extended leave, actually work to slow down women tenure rates while it increases male tenure rates, thus widening the gender gap (Antecol et al., 2018).

For many, the onset of mommy-tracking in academia comes at the same time they are transitioning into motherhood. The mommy tenure track that penalizes women's care choices (i.e., to have children) is a subtle process that gradually ekes away at crucial components for tenure, like first, single, or senior authored publications and competitive grant funding as principal investigator. In the beginning, academic mothers may be shifted to the mommy-track due to the cascading impact of reduced research productivity in the post-partum period followed by caregiving responsibilities inherent to motherhood. Catherine reflected on the difficulty in pursuing single author publications, which are a necessity for promotion in her discipline, due to maternity leave and 
early academic motherhood when her children required more care than older children. Prior to taking leave with her son, Catherine had two single authored publications submitted for review; both were her first and only rejections throughout her career:

Because these are projects I started before getting pregnant with my son, and so this was sort of the stuff that you have to pick up after mat-leave.... Because usually when you're in a team, you know, one person can pick up the slack, or at least can help, you know the moment you get a rejection or something, like you have two minds at work which I think makes a tremendous difference.... So, it says something about the advantages of team work, you know, but I can also see how the process of you know, starting a project and basically not looking at it for eight/nine months, and picking it up again by yourself...and I tried.

Catherine, a mid-career researcher, recalled when her department advised her to prepare and submit her file for promotion during her maternity leave. Despite her reservations, she spent a great deal of time and energy preparing her file, which was ultimately rejected. She recalls feeling particularly frustrated with the rejection and the lack of advice she received in making the submission.

It went well up until the faculty-level committee where there was a majority vote in favour, but not unanimity.... When I assess the situation it just didn't seem smart to put up a fight on that one. I did pass on the story to the union because I thought this is the kind of information that they need to have. But you know, it's also choosing wisely when to fight, when not to fight and this one just didn't seem worth fighting about. [It's] only since a year and a half sort of when that first anger and annoyance [appeared] because I was preparing my tenure file with a six-week-old kid, right? So you know, if you guys would have given me better advice, I wouldn't have to be doing this you know, when I could sleep.

The mommy track also means that when academic mothers submit their file for promotion they are given the additional task of explaining and justifying gaps in productivity that may be a result of maternity leave and care choices. As Erica explained:

When I applied for promotion and tenure this year, when the external letters came back, the reviewers really didn't know how to handle my leaves.... They're asked to compare me to people at a similar point in their career. And they all clearly struggled to do that. And it's understandable. My path has not been a standard path. And it's tough.... You know, so then I feel like I'm explaining a lot. Explaining what the impact is. And l've seen that. l've seen it in other grants... women's grant applications. You're constantly having to say what the impact is of taking a maternity leave. So, I took this long and, you know, it did or didn't impact me in whatever ways. And "Oh, you know, it's okay because I kept working and my students kept working when I was on maternity leave."

Service work-that is, the part of an academic's workload that is comprised of activities focused on developing their department or faculty, much in the same way women conduct care work to develop their children-is often regarded as undesirable because it does not significantly build one's publication record for the tenure file. Women take on more service work, which is a form of academic care work, than their male colleagues (Wijesingha \& Ramos, 2017). Academic mothers often found themselves overwhelmed by service work, which can have the impact of stifling an active research program. Nida recalled with frustration the impact of her various appointments on her research program:

They asked me to stay on for a year [extra before sabbatical] because I was chair of [a key committee].... So, for two years, I chaired [the committee]. Then I went on sabbatical. So, you know, you just start to get your research up and then I came back [to another administrative post]. The research dies.

In academia, the mommy track is also experienced as a series of doubts: doubting one's research program, career path, and even reproductive choices. For many academic mothers like Catherine, the mommy track is an exhausting mental scheme that plays on repeat as you continuously prepare to justify every professional, personal, and family care decision.

And then you know, there are additional things that suck away at your confidence when you're a woman. Mansplaining is in the news, but you know...it sucks away at your confidence. I think it's more internalized.... I was told by people, "Well, you'll never get 
this funded," and you know, that kind of thing....and maybe it wasn't a male thing, and I can remember, and it was very, very far back [a] Dean, and going in to see this person and saying, "I need to talk to you about, sort of, organizing my career." And this person said, "Why are you coming to see me?"

Erica recalled an interaction with a senior colleague that brought her reproductive choices into question. As an early career researcher, it was made it abundantly clear to her that her success would rely heavily upon making her reproductive choices-children and pregnancy-invisible to her colleagues. She recollected the hallway conversation, still in disbelief:

My $\mathrm{PhD}$ supervisor, who was a great man, but when I told him I was pregnant, he said, "Oh, well, you should go and talk to some of the other women in the department, like faculty members, about it. They've had kids, and you would never have known." And I kind of didn't catch it at the moment....and then I walked away and kind of went, whoa, that's horrible.

Academic mothers frequently find themselves relegated to a mommy track in the immediate post-partum period, often as a result of slowed productivity during maternity leave or when trying to restart their research projects following maternity leave alongside increased care responsibilities both in the home and in academia (i.e., service work). From there on, many academic mothers experience the mommy track as a series of lowered expectations, reduced opportunities for promotion, and decreased research capacity.

\section{Research Challenges while Caring}

A masculine ideal is embedded into the academic environment and culture (Dubois-Shaik \& Fusulier, 2017), wherein care work both at home and (ironically) at work are counterproductive to measures of success. In the current academic model, research processes are not equipped to support care work of any kind. Academic mothers are entrenched within the very research processes designed to make care invisible. Conducting research while caring makes explicit the tensions between research methods and motherhood.

Research while caring also encompasses how academic mothers may need to pivot, retract, or reconfigure their research to reflect their care work context and responsibilities. For example, research while caring may alter an academic's mobility patterns. Travel for field work, professional development, and conferences can pose significant challenges to caring. As the primary caregiver, Beth found it nearly impossible to attend conferences until her son was almost three years old.

My friend...was going to a workshop here and a workshop there, and this and that. And I was like oh, oh, oh, I can't. And I guess because I was the primary caregiver, I felt I couldn't leave. So, I only left when my son was almost three, and I went to a conference. And it was.... So, I hadn't left him for almost those three years.

Danielle, an early-career academic mother on the tenure track, employed ethnographic field methods in her research, which required her to spend extended periods of time immersed in the field. Fieldwork became increasingly difficult for her to manage alongside family life; it is an intensive methodology not conducive to care work. She reflected on her choice of research methodology and joked that perhaps she should consider a more quantitative approach.

Like my God, maybe I need to like become a quantitative [researcher] and just like get some data from somewhere and like sit in my office and think about it, yeah.... Yeah, I fantasize about like all my research and stuff, for sure.

Similar to Danielle, Beth is also a qualitative researcher, and while she thinks she would be more productive using quantitative methods, she finds balance in her research through care. Caring, Beth explained, and care work have helped her eke out her research and balance her productivity.

But I like qualitative work. So I wouldn't change because that's what I enjoy doing and that's what I'm good at. But with productivity, sometimes, you know, I feel I'm maybe less productive or work less because I have children. But at the same time, I feel because I have a family, I have more of a balance. So it's more work because it's care work.... And sometimes I have to acknowledge to myself that probably I would not be more productive in terms of maybe more publications or more research or more grants if I didn't have 
children. I'm not sure about that. So sometimes I'm thankful because I have children, no matter how much work and pain and all that it feels, I actually have a more balanced life.

Erica commented that she makes a conscious effort to make her care work visible in the academic environment. In this instance, research while caring entailed not only acknowledging care work in the academic space, but also re-imagining academia as a place that facilitates, rather than hinders, caring.

If my kids are sick, but I have to come into the office, either to pick up some work because I wasn't anticipating it or whatever, I bring my kids with me. Like it's not that they're in the office all the time. They're not running around being crazy. But if they have to come, they come. I brought my two-year-old in for student meetings once because there was nowhere else for him to go. Like I refuse to have it be invisible.... I want people to say, "Hey, look, she has kids and she's doing her job, and she's doing her job well." So I refuse to make it invisible. And I think that's important.

Academic mothers are confronted with the challenge of caring in a space that has historically made such work not only invisible, but counterintuitive to success. As a result, the processes, methods, and traditions that uphold rigorous academic research are not conducive to caring. Research while caring highlights how care work can cause academic mothers to pivot, shift, or reconfigure their academic's research and where academic mothers have sought to integrate their work with care.

\section{Discussion and Conclusions}

Our study explored experiences of motherhood and care on and toward the Canadian tenure track from the perspective of mothers at two Canadian universities. We examined the less visible and nuanced implications of family care work (i.e., the tasks and responsibilities required to maintain a dependent human) on academic mothers' tenure-track journeys in the university over the life course. A feminist thematic analysis of 20 interviews revealed three distinct themes, listed somewhat chronologically: fear of post-partum academic erasure in peak periods of care, mommy-tracking tenure and care choices, and research challenges while caring. The first theme, fear of post-partum academic erasure during peak periods of care, speaks uniquely to the unanticipated impacts of the relatively progressive maternity and parental leave benefits in Canada. The extended physical absence from the academic workplace, from six to 12 months in most cases, invoked fear of academic erasure for faculty mothers. Then, in the post-maternity leave period, participants experienced mommy-tracking as a result of their real or perceived care choices, which saw tenure applications delayed and denied, while departmental service work grew. Finally, our study highlighted the gendered tensions between the academic research process and family care work; researching while caring often necessitated that mothers pivot their research methods, goals, and objectives.

Gendered expectations of care mean that the brunt of family care work (i.e., tasks and responsibilities required to maintain a dependent human life) is carried out by women. In the institutional context of the gender-neutral university, wherein the availability of family-friendly policies and access to parental leave exist as testaments to said neutrality, the gendered impact of family care work is made less visible (Antecol et al., 2018). The university, and in turn the tenure track process, claim gender neutrality when this is not the case; traditional conceptions of productivity remain the ultimate key to success (Lutter \& Schröder, 2020; Lynch, 2010). Taken together, the themes that emerged from our participants' experiences work to highlight the gendered tensions between family care work and academic achievement in the university, despite a policy environment that often claims gender neutrality. As a result, we find that the academic environment is a continuation of a pipeline that is actively pushing out-by an environment that is structurally unfit to support their care needs (Gasser \& Shaffer, 2014)_rather than passively leaking, faculty mothers from its highest ranks (Freeman et al., 2016; Lutter \& Schröder, 2020; Mackenzie, 2015; Resmini, 2016).

For our participants, the tenure-track journey as academic mothers was negatively impacted by concurrent expectations surrounding family care work; they deemed this care work fundamentally incompatible with academic processes deemed critical to success (e.g., publication, research continuity, and promotion). This incompatibility has been partly characterized by an academic gender gap, which is a term used to describe a series of factors that explain the gender differences in academia 
(Baker, 2010). The academic gender gap, however, does little to fully engage with how gendered expectations around family care work are comprised of more than visible processes, like access to childcare and leave, and include less visible processes like academic erasure and mommy-tracking. Our participants speak of the way in which caring becomes entangled with the academic process at every turn; effectively reorganizing how they move through the tenure track system and experience academia.

As an exploratory study, our study was limited by the small sample size and specific geographical location. All of the interviews were conducted with women at two Canadian universities; the culture and experiences may be particular to their location and could have affected how and why certain themes emerged. Similarly, because Canadian employment insurance benefits provide for access to ample maternity and parental leave benefits and employer top-ups, our participants did not take issue with the amount of leave or access to leave. Indeed, the post-partum leave experience would be drastically different in an environment that did not have these benefits in place (i.e., the United States). Additionally, as tenure-track academics, our research participants all experience a moderate degree of job security when compared to their contract or adjunct counterparts.

Future research should endeavour to consider experiences of academic motherhood and caring in the pandemic and post-pandemic academic environment. We know from emerging research and data that the COVID-19 global public health crisis has had important implications for women's research productivity in academia (Oleschuk, 2020; McCormick, 2020; Miller, 2021; Yildirim \& Eslen-Ziya, 2020). A recent study found that in the 10 weeks following lockdown in the United States, men's research productivity increased by $35 \%$ while women's fell by more than $13 \%$ (Cui et al., 2020). School and daycare closures have imposed increased expectations of care on women and effectively widened the productivity gap. It is unknown how or when faculty mothers and women, more broadly, will make up for this growing gap. The findings of this study have could have important implications for practice, including: reconsidering how the university assesses tenure and promotion in the context of care, increased acceptance and inclusion of a researcher's positionality as it relates to care, and more institutional supports for mothers on the tenure track (e.g., structured mentorship opportunities, decreased service work, writing groups, childcare cooperatives, etc.) Future research should assert the importance of caring through academic processes and work to make such work visible throughout the tenure track.

Ultimately, the university must embrace a culture of care that is founded in the same tenets of equity, diversity, and inclusion it purports to champion. In the coming months and years, we will begin to see results from the Dimensions: Equity, Diversity, and Inclusion Canada program, which is supported by the three federal researching granting agencies (the Natural Sciences and Engineering Research Council, the Canadian Institute of Health Research, and the Social Sciences and Humanities Research Council). The Dimensions program endeavours to foster transformative change in the research ecosystem and, in doing so, must meaningfully address the role of gendered care work in the research process. Cultivating a research ecosystem that embraces care must develop inclusive and equitable policies, programs, and cultures that truly value care, care work, and those who care in the research ecosystem.

\section{References}

Acker, S., Webber, M., \& Smyth, E. (2012). Tenure troubles and equity matters in Canadian academe. British Journal of Sociology of Education, 33(5), 743-761. https://doi.org/10.1080/01425692.2012.6 $\underline{74784}$

Acker, S., \& Armenti, C. (2004). Sleepless in academia. Gender and Education, 16(1), 3-24. https://doi.org/ 10.1080/0954025032000170309

Allen, S., Klein, S. R., \& Hill, E. J. (2008). Framing carework: Context, processes and outcomes. Journal of the Motherhood Initiative for Research and Community Involvement, 10(1), 20-32. https:/l jarm.journals.yorku.ca/index.php/jarm/article/ view/16327/15186

Antecol, H., Bedard, K., \& Stearns, J. (2018). Equal but inequitable: Who benefits from gender-neutral tenure clock stopping policies? American Economic Review, 108(9), 2420-2441. https://doi. org/10.1257/aer.20160613

Armenti, C. (2004). May babies and posttenure babies: 
Maternal decisions of women professors. The Review of Higher Education, 27(2), 211-231. https:Il doi.org/10.1353/rhe.2003.0046

Armstrong, P., \& Armstrong, H. (2002). Thinking it through: Women, work and caring in the new millennium. Canadian Woman Studies, 44, 211-231. https://doi.org/10.3138/9781442602410-003

Baker, M. (2010). Career confidence and gendered expectations of academic promotion. Journal of Sociology, 46(3), 317-334. https://doi. org/10.1177\%2F1440783310371402

Beigi, M., Shirmohammadi, M., \& Stewart, J. (2018). Flexible work arrangements and work-family conflict: A metasynthesis of qualitative studies among academics. Human Resource Development Review, 17(3), 314-336. https://doi. org/ $10.1177 \% 2$ F 1534484318787628

Benoit, C., \& Hallgrimsdóttir, H. (Eds.). (2011). Valuing care work: Comparative perspectives. University of Toronto Press.

Bonawitz, M., \& Andel, N. (2009). The glass ceiling is made of concrete: The barriers to promotion and tenure of women in American academia. Forum on Public Policy Online, 2009(2), 1-16. https://files. eric.ed.gov/fulltext/EJ870462.pdf

Bosanquet, A. (2017). Academic, woman, mother: Negotiating multiple subjectivities during early career. In R. Thwaites \& A. Pressland (Eds.), Being an early career feminist academic (pp. 73-91). Palgrave Macmillan.

Bourgault, S., \& J. Perreault (Eds.). (2013). Le care: éthique féministe actuelle. Éditions du Remue-Ménage Montréal.

Braun, V., \& Clarke, V. (2006). Using thematic analysis in psychology. Qualitative Research in Psychology, 3(2), 77-101. https://doi. org/10.1191/1478088706QP0630A

Castaneda, M., \& Isgro, K. (Eds.). (2013). Mothers in academia. Columbia University Press.

Cui, R., Ding, H., \& Zhu, F. (2020). Gender inequality in research productivity during the COVID-19 pandemic. Manufacturing \& Services Operation Man- agement (advance article). https://doi.org/10.1287/ msom.2021.0991

Daniels, A. K. (1987). Invisible work. Social Problems, 34(5), 403-415. https://doi.org/10.2307/800538

Denson, N., Szelényi, K., \& Bresonis, K. (2018). Correlates of work-life balance for faculty across racial/ethnic groups. Research in Higher Education, 59(2), 226-247. https://doi.org/10.1007/s11162017-9464-0

Drakich, J., Stewart, M., \& Ornstein, M. (2007). Promotion at Canadian universities: The intersection of gender, discipline, and institution. Canadian Journal of Higher Education, 37(3), 1-25. https:/l files.eric.ed.gov/fulltext/EJ799705.pdf

Drago, R., Colbeck, C., Stauffer, K. D., Pirretti, A., Burkum, K., Fazioli, J., Lazarro, G., \& Habasevich, T. (2005). Bias against care giving. Academe, 91(5), 22-25. https://doi.org/10.2307/40252829

Drago, R., \& Williams, J. (2010). A half-time tenure track proposal. Change: The Magazine of Higher Learning, 32(6), 46-51. https://www.tandfonline.com/doi/ abs/10.1080/00091380009601767

Dubois-Shaik, F., \& Fusulier, B. (2017). Understanding gender inequality and the role of work/family interface in contemporary academia: An introduction. European Educational Research Journal, 16, 99105. https://doi.org/10.1177\%2F1474904117701143

England, P., Budig, M., \& Folbre, N. (2002). Wages of virtue: The relative pay of care work. Social Problems, 49(4), 455-473. https://doi.org/10.1525/ sp.2002.49.4.455

England, P. (2005). Emerging theories of care work. Annual Review of Sociology, 31, 381-399.

Finkel, S. K., \& Olswang, S. G. (1996). Child rearing as a career impediment to women assistant professors. The Review of Higher Education, 19(2), 123-139. https://doi.org/10.1353/rhe.1996.0027

Freeman, B. K., Landry, A., Trevino, R., Grande, D., \& Shea, J. A. (2016). Understanding the leaky pipeline: Perceived barriers to pursuing a career in medicine or dentistry among underrepresented-in-medicine undergraduate students. Academic 
Medicine, 91(7), 987-993. https://doi.org/10.1097/ ACM. 0000000000001020

Gaudet, S. (2013). Comprendre les parcours de vie à la croisée du singulier et de la structure sociale. In S. Gaudet, N. Burlone, \& M. Lévesque (Eds.), Repenser la famille et ses transitions repenser les politiques publiques (pp. 15-50). Presses de l'Université Laval.

Gaudet, S., \& Robert, D. (2018). A journey through qualitative research: From design to reporting. Sage.

Gasser, C. E., \& Shaffer, K. S. (2014). Career development of women in academia: Traversing the leaky pipeline. https://mdsoar.org/bitstream/ handle/11603/5410/GASSER $\% 20 \% 26 \% 20$ SHAFFER\%20-\%20WOMEN\%20IN\%20ACADEMIA. pdf? sequence $=3 \&$ isAllowed $=y$

Gottfried, H. (2013). Gender, work, and economy: Unpacking the global economy. John Wiley \& Sons.

Hill, M. S., Nash, A., \& Citera, M. (2011). Parenthood in academia: What happens when there is no policy? Wagadu: A Journal of Transnational Women's \& Gender Studies, 9, 113-139. http://sites.cortland. edu/wagadu/wp-content/uploads/sites/3/2014/02/ parenthoodlnAcademia.pdf

Hirakata, P. E., \& Daniluk, J. C. (2009). Swimming upstream: The experience of academic mothers of young children. Canadian Journal of Counselling, 43(4), 283-294. https://files.eric.ed.gov/fulltext/ EJ858081.pdf

Kandiko, C. B., Coate, K., \& de St Croix, T. (2018). Mid-career academic women and the prestige economy. Higher Education Research \& Development, 37(3), 533-548. https://doi.org/10.1080/0729 4360.2017.1411337

Kolker Finkel, S., \& Olswang, S. G. (1996). Child rearing as a career impediment to female assistant professors. Review of High Education, 19(2), 123-39. https://doi.org/10.1353/rhe.1996.0027

Lutter, M., \& Schröder, M. (2020). Is there a motherhood penalty in academia? The gendered effect of children on academic publications in German sociology. European Sociological Review, 36(3), 442-459. https://doi.org/10.1093/esr/jcz063
Lynch, K. (2010). Carelessness: A hidden doxa of higher education. Arts and Humanities in Higher Education, 9(1), 54-67. https://doi. org/10.1177/1474022209350104

Mackenzie, B. (2015). The "leaky pipeline": Examining and addressing the loss of women at consecutive career stages in marine engineering, science and technology. In M. Kitada, E. Williams, \& L. Loloma Froholdt (Eds.), Maritime women: Global leadership (pp. 69-81). Springer.

Mason, M. A., Wolfinger, N. H., \& Goulden, M. (2013). Do babies matter? Gender and family in the ivory tower. Rutgers University Press.

McCormick, C. M. (2020). Disparities in the toll of the COVID-19 pandemic on publishing: Evidence from submissions to Hormones and Behavior. Hormones and Behavior, 124, 104814. https://dx.doi. org/10.1016\%2Fj.yhbeh.2020.104814

Miller, K. E. (2021). The ethics of care and academic motherhood amid COVID-19. Gender, Work \& Organization, 28, 260-265. https://doi.org/10.1111/ gwa0.12547

Momani, B., Dreher, E., \& Williams, K. (2019). More than a pipeline problem: Evaluating the gender pay gap in Canadian academia from 1996 to 2016. The Canadian Journal of Higher Education, 49(1), 1-21. https://doi.org/10.7202/1060821ar

Oakley, A. (1981). Interviewing women: A contradiction in terms. Doing Feminist Research, 30(6), 1.

O'Brien, J. (Ed.). (2009). Encyclopedia of gender and society (Vol. 1). Sage. http://dx.doi. org/10.4135/9781412964517

O'Laughlin, E., \& Bischoff, L. (2005). Balancing parenthood and academia: Work/family stress as influenced by gender and tenure status. Journal of Family Issues, 36(1), 79-106. https://doi. org/10.1177/0192513X04265942

Oleschuk, M. (2020). Gender equity considerations for tenure and promotion during COVID-19. Canadian Review of Sociology, 57(3), 502-515. https://dx.doi. org/10.1111\%2Fcars.12295

Resmini, M. (2016). The 'leaky pipeline.' Chemistry- $A$ 
European Journal, 22(11), 3533-3534. https://doi. org/10.1002/chem.201600292

Reverby, S. (1994). A caring dilemma: Womanhood and nursing in historical perspective. In E. C. Hein \& M. J. Nicholson (Eds.), Contemporary leadership behavior: Selected readings (4th ed., pp. 3-15). J. B. Lippincott.

Rich, A. (1995). On lies, secrets, and silence: Selected prose 1966-1978. W. W. Norton \& Company.

Schwartz, F. (1989). Management women and the new facts of life. Harvard Business Review, 67(1), 5-14. https://www.emerald.com/insight/content/ doi/10.1108/EUM0000000001789/full/html

Spalter-Rother, R., \& Erskine, W. (2005). Beyond the fear factor: Work/family policies in academia-Resources or rewards? Change, 37(6), 18-25. https:ll doi.org/10.3200/CHNG.37.6.19-25

Star, S. L., \& Strauss, A. (1999). Layers of silence, arenas of voice: The ecology of visible and invisible work. Computer Supported Cooperative Work (CSCW), 8(1-2), 9-30. https://doi. org/10.1023/A:1008651105359

Statistics Canada. (2017). A profile of academic staff. https://www23.statcan.gc.ca/imdb/p2SV.pl?Function=getSurvey $\&$ SDDS $=3101$

Statistics Canada. (2020). Number of proportions of full-time teaching staff at Canadian universities by rank sex. https://www150.statcan.gc.ca/t1/tbl1/en/ cv.action?pid=3710014401

Thanacoody, P. R., Bartram, T., Barker, M., \& Jacobs, K. (2006). Career progression among female academics. Women in Management Review, 21(7), 536553. https://doi.org/10.1108/09649420610692499

Tronto, J. C. (1993). Moral boundaries: A political argument for an ethic of care. Psychology Press.

University Affairs. (2017). A history of Canada's full-time faculty in six charts. https://www. universityaffairs.ca/features/feature-article/history-canadas-full-time-faculty-six-charts/

Valian, V. (2005). Beyond gender schemas: Improving the advancement of women in academia. Hypatia, 20(3), 198-213. https://www.cambridge.org/corel journals/hypatia/article/abs/beyond-gender-schemas-improving-the-advancement-of-women-in-academia/6D68206EE09D7859E5ED1458EA7E3655

Van Anders, S. M. (2004). Why the academic pipeline leaks: Fewer men than women perceive barriers to becoming professors. Sex Roles, 51(9-10), 511521. https://www.springer.com/journal/11199

Ward, K., \& Wolf-Wendel, L. (2016). Academic motherhood: Mid-career perspectives and the ideal worker norm: Academic motherhood: Mid-career. New Directions for Higher Education, 2016(176), 11-23. https://doi.org/10.1002/he.20206

Ward, K., Wolf-Wendel, L., Marco, L. A., Camp, S., Sams, K., Dixon, L. Z., \& Karram, J. F. (2019). Mothering from the field: The impact of motherhood on site-based research. Rutgers University Press.

Weber, C. A. (2009). Mommy track. Encyclopedia of Gender and Society, 2, 576-577. Sage.

Williams, J. C. (2000). Unbending gender: Why family and work conflict and what to do about it. Oxford University Press.

Williams, J. C. (2004). Hitting the maternal wall - Before they reach a "glass ceiling" in their careers, women faculty may hit a "maternal wall." Academe Bulletin of the American Association of University Professors, 90, 16. https://repository.uchastings. edu/cgi/viewcontent.cgi?article=2201\&context=faculty scholarship

Wilton, S., \& Ross, L. (2017). Flexibility, sacrifice and insecurity: A Canadian study sssessing the challenges of balancing work and family in academia. Journal of Feminist Family Therapy, 29(1-2), 66-87. https://doi.org/10.1080/08952833.2016.127 $\underline{2663}$

Wijesingha, R., \& Ramos, H. (2017). Human capital or cultural taxation: What accounts for differences in tenure and promotion of racialized and female faculty? Canadian Journal of Higher Education / Revue Canadienne d'enseignement Supérieur, 47(3), 54-75. https://doi.org/10.7202/1043238ar

Wolfinger, N. H., Mason, M. A., \& Goulden, M. (2008). Problems in the pipeline: Gender, marriage, and fertility in the ivory tower. The Journal of Higher 
Education, 79(4), 388-405. https://doi.org/10.1080/ $\underline{00221546.2008 .11772108}$

Wolf-Wendel, L. E., \& Ward, K. (2006). Academic life and motherhood: Variations by institutional type. Higher Education, 52(3), 487-521. https://doi. org/10.1007/s10734-005-0364-4

Yildirim, T. M., \& Eslen-Ziya, H. (2020). The differential impact of COVID-19 on the work conditions of women and men academics during the lockdown. Gender, Work \& Organization, 28(51), 243-249. https://doi.org/10.1111/gwao.12529

\section{Contact Information}

Yvonne James

yjame033@uottawa.ca

\section{Notes}

1 The latest data on tenured faculty, full-time lecturers, and instructors reflect the responses of 112 public universities and affiliated colleges for 2016 to 2017. 